\title{
Performance of a Water Suction System Using Hydrophilic Fibrous Cloth under Low Gravity and Microgravity in Parabolic Flight
}

\author{
Akira TANI, Takahiro SaIto, ${ }^{* 1}$ Yoshiaki KITAYA, ${ }^{* 2}$ \\ Hideyuki TAKAHASHI*3 and Eiji GoTO*4 \\ School of High-Technology for Human Welfare, Tokai University, Numazu 410-0395, Japan \\ *1 Department of Environmental Engineering, Utsunomiya University, Utsunomiya 321-8505, Japan \\ ${ }^{* 2}$ Faculty of Agriculture, Osaka Prefecture University, Sakai 599-8531, Japan \\ *3 Institute of Genetic Ecology, Tohoku University, Sendai 980-8577, Japan \\ ${ }^{* 4}$ Graduate School of Agricultural and Life Sciences, The University of Tokyo, \\ Tokyo 113-8657, Japan
}

(Received December 1, 1999)

\begin{abstract}
For suction of water from a water supply vessel including both water and air under microgravity and $g$-jitter conditions, a water suction system using hydrophilic fibrous cloth was developed and its performance was evaluated at 0.01-0.02 g-realized for $20 \mathrm{~s}$ by parabolic flight in an aircraft. Vessels used for the experiment were glass flasks and had a suction port for suction filtration. A piece of hydrophilic fibrous cloth was arranged along the inner surface of the vessels and the end was fixed to the suction port of the vessels. In vessel without hydrophilic cloths and containing $220 \mathrm{~mL}$ of water, the water did not move more than $5 \mathrm{~mm}$ along the inner surface and did not reach the suction port under low gravity. When hydrophilic cloths were used, on the other hand, water gathered onto the cloth surface, moved up along the cloth and reached the suction port under low gravity. The amount of water sucked from vessels varied with the amount of water in the vessel and the sectional area of hydrophilic cloths. When the vessels including both water and air were flown during parabolic flight $\left(10^{-4} \mathrm{~g}\right)$, water in the vessel moved along the cloth and a water film was formed on the cloth. These results indicated that it is possible to suck water using the fibrous cloth suction system under low gravity and microgravity conditions. Under low gravity conditions, it was difficult to suck water only. However, it is not necessary to separate water from air when the system is used for supplying water to plant root medium consisting of both liquid and gas phases.
\end{abstract}

\section{INTRODUCTION}

A plant growth chamber for experiments under microgravity (Space Plant Box, SPB) has been fabricated by researchers in Japanese universities (Kitaya et al., in press). The SPB is a controlled environmental chamber not only for short-term vegetative growth experiments but also for reproductive growth experiments such as long-term seed to seed experiments. Most water will be recycled by condensing water vapor transpired by higher plants in SPB (Tani et al., 1998). However, a water supply system should also be included with the SPB because an increase in amount of water absorbed by plants could lead to a decrease in water content in root medium. The system has to operate under microgravity. 
When water and air are present in a hydrophilic vessel under microgravity, water tends to spread along the inner surface of the vessel to increase its contact area (Imaishi, 1994a), and a globular shaped air bubble appears in the center of the vessel. When the vessel is hydrophobic, on the other hand, water tends to leave the inner surface and form a globular shaped domain in the vessel.

Use of a hydrophilic vessel makes it possible to suck water from a suction port under zero gravity. However, in the orbit of the International Space Station (ISS), microgravity $\left(10^{-5}\right.$ $10^{-4} \mathrm{~g}$ ) conditions remain and vibration and crew activity often cause small accelerations (so-called $g$-jitter), which might disturb zero-gravity experiments such as crystal formation (Imaishi, 1994b). Water supply systems have to operate appropriately under these gravity conditions.

We developed a water suction system using hydrophilic fibrous cloth. The cloth was more hydrophilic than the inner surface of the water supply vessel, causing water to concentrate on the cloth. In the experiment, the performance of the system was evaluated under low gravity and microgravity realized by parabolic flight of an aircraft.

\section{MATERIALS AND METHODS}

1. Aircraft experiment. The aircraft used for parabolic flight was an MU300 (Mitsubishi Heavy Industry Co. Ltd.). Five flights were carried out on different dates from February 24 to March 5 in 1999. Low gravity of $0.01-0.02 \mathrm{~g}$ was realized for about $20 \mathrm{~s}$ by flying the aircraft in a parabola (Fig. 1). Five to ten parabolic flights were carried out in each flight. Just before the low gravity condition, a gravity of about $2 g$ continued for 20-30 s. After achieving low gravity, a gravity level of about $1.5 \mathrm{~g}$ continued for $20 \mathrm{~s}$ and then returned to normal $(1 \mathrm{~g})$. Accelerations to the forward and lateral directions of the aircraft varied within $\pm 0.01 \mathrm{~g}$ during low gravity ( $x$ - and $y$-axes in Fig. 1). Air pressure and temperature in the aircraft were maintained at $92 \mathrm{kPa}$ and $20^{\circ} \mathrm{C}$, respectively, during the parabolic flights.

2. Water suction experiment under low gravity. A water suction experiment was carried out using vessels on the inner surface of which were glued pieces of hydrophilic fibrous cloth (Fig. 2). Pieces of glass fibrous cloth (NSC 550-84, Nippon Glass Fiber Co. Ltd.) and rayon fibrous cloth (Toyobo Co. Ltd.) were used as hydrophilic fibrous cloth. The sizes of rayon and glass cloths were $3 \times 10 \mathrm{~cm}$ and $1 \times 10 \mathrm{~cm}$, respectively. The thickness of rayon and glass cloths was about 0.5 and $1 \mathrm{~mm}$, respectively. Each cloth was placed along the inside of the vessel and the end was fixed to the suction port of the vessel. Vessels used for experiment were $300 \mathrm{~mL}$ flat-bottomed glass flasks (Tokyo Glass Kiki Co. Ltd.; referred to as vessel A hereafter) and $300 \mathrm{~mL}$ round-bottomed glass flasks (Sansyo Co. Ltd.; referred to as vessel B hereafter). Both the vessels had a suction port for filtration. Water amount was 30 and 220 $\mathrm{mL}$ in vessel B where the suction port was above the water surface, and $100 \mathrm{~mL}$ in vessel A where the port was below the water surface. Silicone corks were used as lids for the vessels. A ventilation port $(5 \mathrm{~mm}$ in diameter) was made at the center of each cork. The port was covered with a fluorocarbon filter (pore size: $0.5 \mu \mathrm{m}$, FWMSO1800, Millipore Co. Ltd.). This prevented water from passing through the port during the flight experiment. A Teflon tube ( $3 \mathrm{~mm}$ inside diameter) was connected to the suction port, and its opposite end was connected to a roller pump (FK-20D, Furue Science Co. Ltd.).

An electric signal was produced if low gravity (less than $0.02 \mathrm{~g}$ ) continued for $2 \mathrm{~s}$ in the aircraft. A sequencer (Fxon-24MR, Mitsubishi Co. Ltd.) switched the pump on and off for 7 and $15 \mathrm{~s}$, respectively, after receiving this signal. In planning the experiment, we predicted that several seconds would be needed for water movement to become stable under low gravity. Actually, water reached a stable condition within $3 \mathrm{~s}$ in all experiments. 

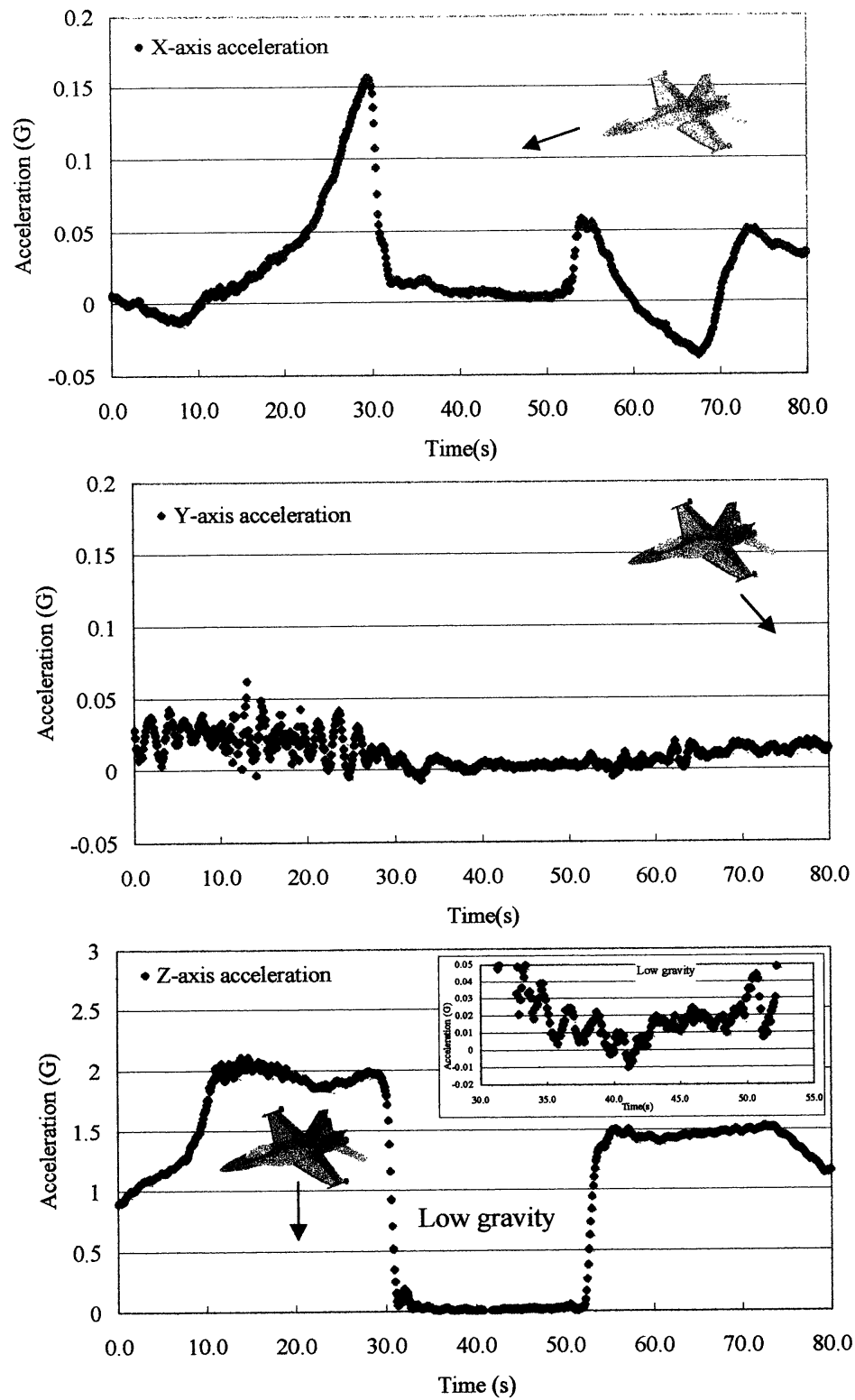

Fig. 1 Changes in accelerations to the forward $(x)$, lateral $(y)$ and vertical $(z)$ directions of the aircraft.

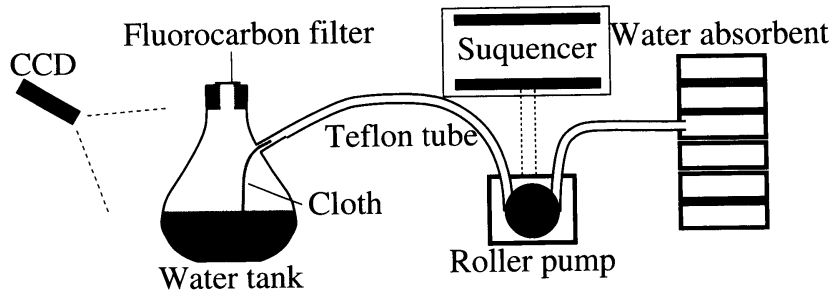

Fig. 2 Schematic diagram of water suction system using hydrophilic fibrous cloth. 
The Teflon tube was connected to the exhaust port of the pump, and the opposite end was fixed in one of 10 polymer water absorbents (Cyamu Co. Ltd.). A different polymer absorbent was used for each parabolic flight. The absorbent absorbed water exhausted by the pump for $8 \mathrm{~s}$ under low gravity. Amount of water sucked up was determined by weighing the absorbent on the ground before and after the flight.

To observe water movement in the vessels, we videotaped the vessel using a CCD camera (EM102, Elemo Co. Ltd.) fixed at a distance of $20 \mathrm{~cm}$ from the vessels. A very small amount of coloring material (Cut Color Red, Daiichi Engei Co. Ltd.) was added to the water to aid visualization.

All experimental devices were arranged and fixed in an experimental rack measuring $450 \times 700 \times 900 \mathrm{~mm}$.

3. Floating experiment during parabolic flights. When an object is floated in an aircraft during parabolic flight, acceleration exerted on the object decreases to $10^{-4} \mathrm{~g}$ (Kudo, 1994). The acceleration of the gravity is referred to hereafter as microgravity. This gravitational field is similar to that in the ISS. In the experiment, vessels including both water and air were floated in the aircraft, and water movement in vessels was videotaped with a CCD camera (CCD-TR11, Sony Co. Ltd.). The glass vessel A and cylindrical polycarbonate vessels $(300 \mathrm{~mL})$ were used for the experiment. The amount of water in vessel A was $30 \mathrm{~mL}$. A piece of rayon cloth $(3 \times 8 \mathrm{~cm})$ was glued to the inner surface of the polycarbonate vessels, and 50 or $200 \mathrm{~mL}$ of water was added to each vessel.

\section{RESULTS AND DISCUSSION}

\section{Results of water suction experiment}

Figure 3 shows the vessels videotaped under $1 g$ and low gravity. When gravity changed from $2 \mathrm{~g}$ to low gravity, water moved about $2 \mathrm{~cm}$ along the inner surface of vessel A containing $100 \mathrm{~mL}$ of colored water but no hydrophilic cloths, and a concave water surface appeared (Fig. $3 b$ ). The pump could suck only water. In vessel B containing $220 \mathrm{~mL}$ of water but no hydrophilic cloths, the water did not move more than $5 \mathrm{~mm}$ along the inner surface and did not reach the suction port under low gravity (Fig. 3d). The inhibition of upward water movement along the inner surface was thought to have been due to the low gravity during parabolic flight. In vessel B where a piece of hydrophilic rayon cloth was placed along the inside and the end was fixed to the suction port, water gathered onto the cloth surface, moved up along the cloth and reached the suction port under low gravity (Fig. 3f). Then, the pump sucked both water and air. Water also moved up and reached the suction port even in vessel B containing a very small amount $(30 \mathrm{~mL})$ of water (Fig. $3 \mathrm{~h})$. With a piece of hydrophilic glass cloth, water also moved up along the inner surface and could be sucked up by the pump (Fig. 3j).

Figure 4 shows the amount of water sucked by a roller pump. The amount of water sucked in the first parabolic flight was less than those in the other parabolic flights because of the lack of water in the tube between the pump and suction port. The amount of water sucked from vessel A containing $100 \mathrm{~mL}$ of water and no cloth, where the port was below the water surface, was about $5.8 \mathrm{~mL}$ per parabolic flight (control). The amount of water sucked from vessel B containing $220 \mathrm{~mL}$ of water and rayon cloth, where the suction port was above the water surface, was $85 \%$ of control. Air was also sucked from the vessel by the pump, which resulted in a decrease in amount of sucked water. Use of the glass cloth decreased the amount of water and increased that of air sucked from vessel B because the lower sectional area of the cloth decreased water transport efficiency. Only a small amount of water could be sucked from vessel B containing $30 \mathrm{~mL}$ of water and rayon cloth. Thus, it was possible to suck water 

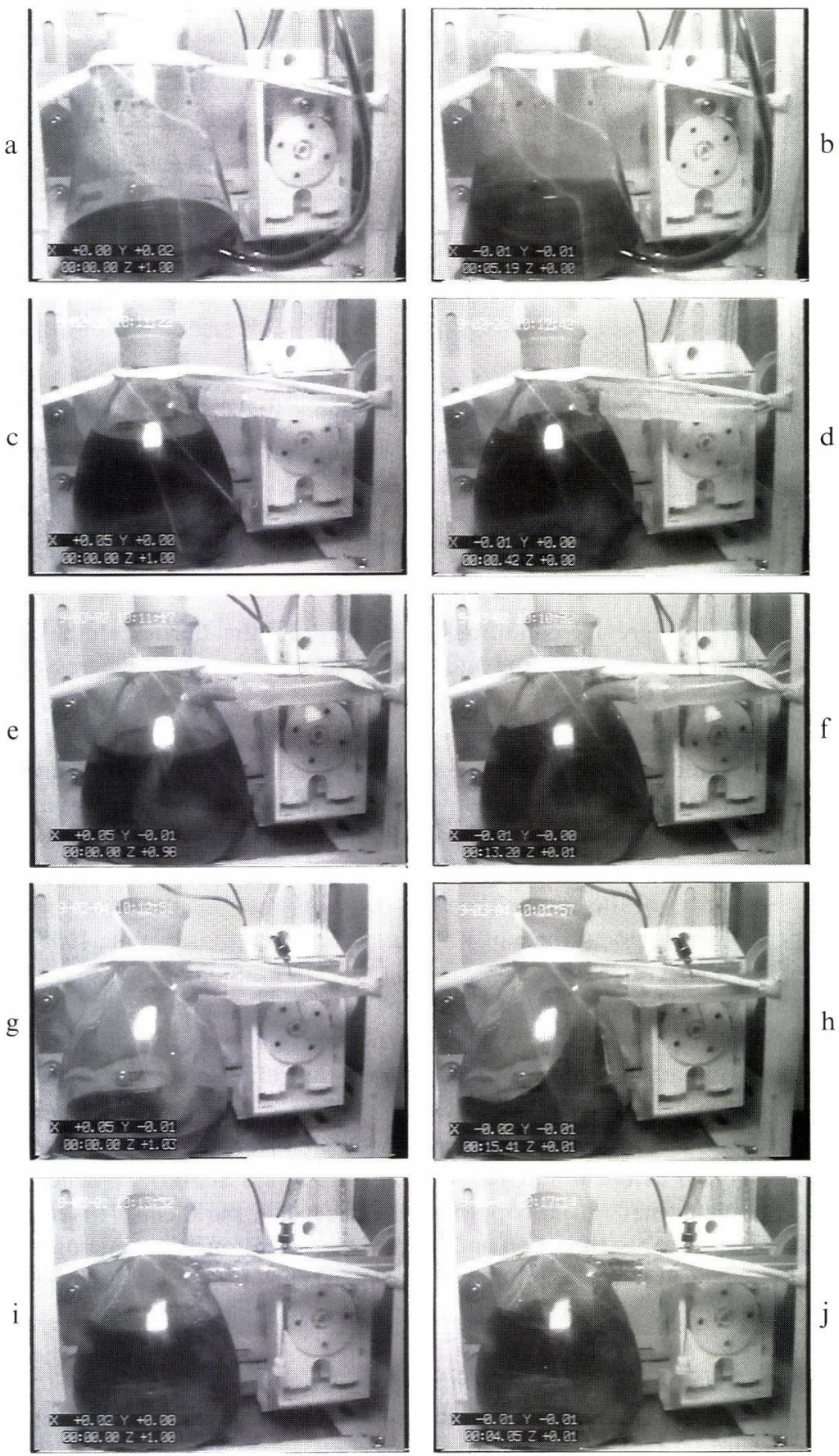

Fig. 3 Water in the vessels under $1 \mathrm{~g}$ (left) and low gravity (right).

a, b : $100 \mathrm{~mL}$ water in vessel A; c, d : $220 \mathrm{~mL}$ water in vessel B; e, f: $220 \mathrm{~mL}$ water in vessel B with rayon cloth; $\mathrm{g}, \mathrm{h}: 30 \mathrm{~mL}$ water in vessel $\mathrm{B}$ with rayon cloth; $\mathrm{i}, \mathrm{j}: 220 \mathrm{~mL}$ water in vessel $\mathrm{B}$ with glass cloth. 


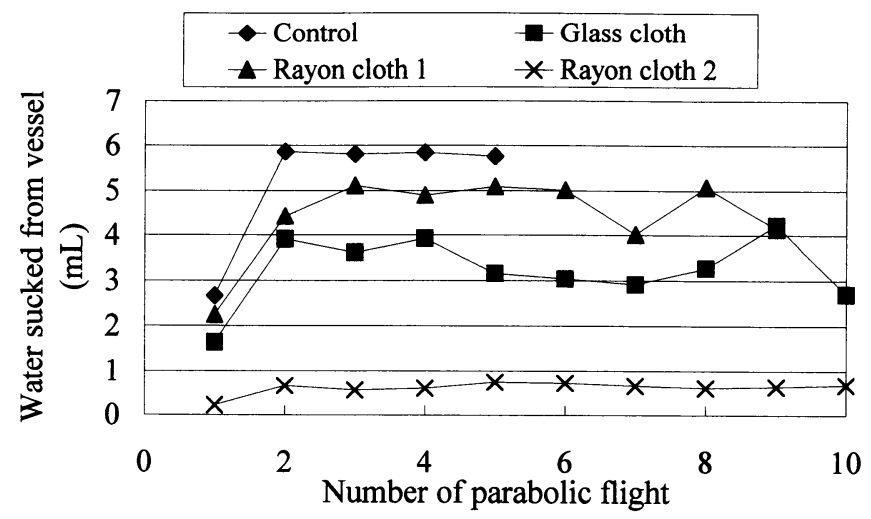

Fig. 4 Amounts of water sucked from the vessels by the roller pump with or without hydrophilic fibrous cloth under low gravity

Water in vessel : control, $100 \mathrm{~mL}$; glass cloth, $220 \mathrm{~m}$; rayon cloth $1,220 \mathrm{~mL}$; rayon cloth 2,30 $\mathrm{mL}$. Sucking position of control only was below the water surface under ground gravity.

from vessels under low gravity conditions using hydrophilic fibrous cloth. Hydrophilic fibrous cloth was effective for gathering and transporting water under low gravity conditions.

\section{Results of floating experiment}

Figure $5 \mathrm{~b}, \mathrm{~d}, \mathrm{f}$ and $\mathrm{h}$ show pictures of water in the vessels floated in the aircraft during parabolic flight (microgravity). The water was spread widely along the inner surfaces of both the polycarbonate vessel and glass vessel $\mathrm{A}$ and a globular shaped air bubble appeared in the center of the vessels. However, water distribution was not uniform, and was especially likely to gather in the corners of the vessels (Fig. 5d, f). This was because of a greater capillary action and increased adhesional force of water at the corners (Marui et al., 1995). Nagaoka et al. (1994) made a port at an acute angle to inject liquid into a diamond-shaped cell culture chamber and successfully injected liquid without air under low gravity.

On the other hand, in the vessels with a piece of hydrophilic rayon cloth glued to the inner surface water always gathered and formed a film on the cloth under microgravity (Fig. $5 \mathrm{~h}$ ). This might have been because wettability of the cloth was greater than that of vessel material, which resulted in a smaller interface tension between the cloth and water (Ono, 1997). Furukawa et al. (1991) used a liquid vessel to separate liquid and air, in which hydrophilic and tapered core plates made from copper were arranged in parallel. This shape of vessel could reorient water by capillary action and/or the surface tension under microgravity. Their and our results suggested that the appropriate arrangement of more hydrophilic materials in liquid vessels would enable us to reorient and gather water under microgravity.

\section{Advantage of the water suction system using hydrophilic fibrous cloth}

Flexible tanks capable of expansion and contraction are widely used as water supply tanks under conditions of microgravity (Furukawa et al., 1992 ; Bingham et al., 1996). Water is separated from air with various kinds of liquid/air separators (Yoda et al., 1992; Hoehn et al., 1997) and then accumulated in these tanks. However, addition of liquid/air separators to the water supply system is not desirable in terms of space and power usage.

In this experiment, it was possible to suck water from non-flexible vessels using hydrophilic fibrous cloth. When fluid consisting of both water and air was sent to the vessel, water seemed to gather onto cloth that was more hydrophilic than the material of the vessel and 

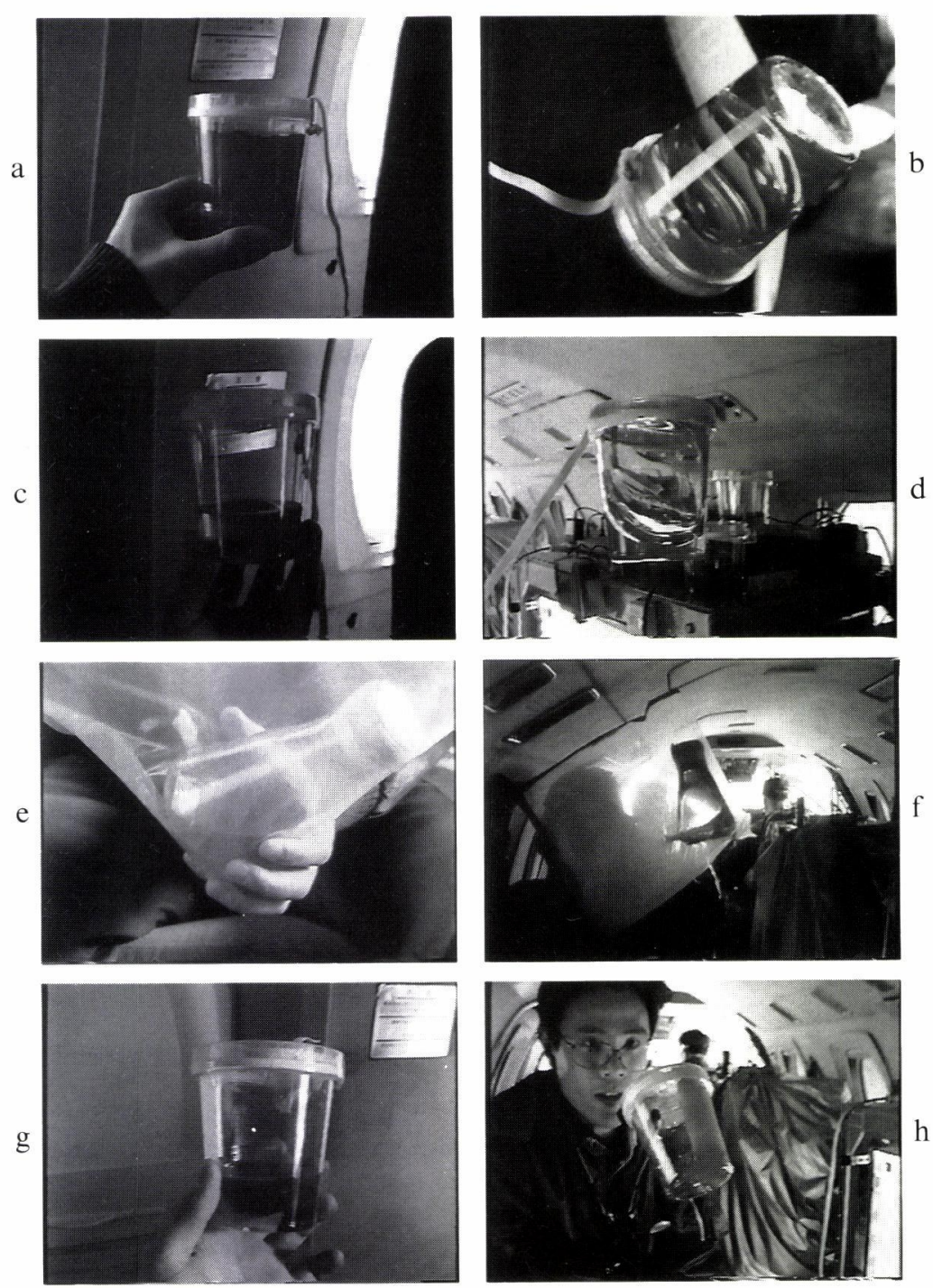

Fig. 5 Water in the vessels under $1 \mathrm{~g}$ (left) and microgravity (right).

a, b : $200 \mathrm{~mL}$ water in polycarbonate vessel ; c, d : $50 \mathrm{~mL}$ water in polycarbonate vessel ; e, f : 30 $\mathrm{mL}$ water in vessel $\mathrm{A} ; \mathrm{g}, \mathrm{h}: 50 \mathrm{~mL}$ water in polycarbonate vessel with rayon cloth.

could be naturally separated from air (Suzuki et al., 1997). In our system, the air pressure in the vessel could be kept almost constant because air sent by the pump was released through the fluorocarbon filter. It is not necessary to remove the air from the fluid exhausted to root medium by the pump because plant roots need oxygen. The water supply system using hydrophilic fibrous cloth, as well as the vessel developed by Furukawa et al. (1991) described previously, are available for plant growth chambers under microgravity such as the SPB.

\section{CONCLUDING REMARKS}

Our experimental results suggested that it was possible to gather water into and suck water 
from the suction port of the glass vessels using hydrophilic fibrous cloth under gravity of 0.01 $0.02 \mathrm{~g}$. The water suction system using hydrophilic fibrous cloth seems to operate well under microgravity as well as low gravity because water spread over the cloth glued onto the inner surface of the vessels. These findings indicated that this water suction system can suck up water under fluctuating gravitational conditions or $g$-jitter. The pump used to send water to the root medium cannot always suck water only. However, it is not necessary to separate water from air because both liquid and air phases exist in root medium.

This work was supported by a Grant-in-Aid from the Japan Space Forum. We are grateful to Mr. Otsubo of the Institute for Environmental Science and Mr. Oshima and Mr. Fujimori of Kawasaki Heavy Industries Co. Ltd. for their helpful advice. We are also grateful to undergraduate students Ms. Tahara and Ms. Seino of Tokai University, and assistants of Diamond Air Service Co. for their help.

\section{REFERENCES}

Bingham, G. E., Salisbury, F. B., Campbell, W. F., Carman, J. G., Buhenheim, D. L., Yendler, B., Sytchev, V. N., Berkovitch, Y. A., Levinskikh, M. A., Podolsky, I. G. 1996. The spacelab-MIR-1 “Greenhouse-2" experiment. Adv. Space Res. 18 (4/5) : 225-232.

Furukawa, M., Ishii, Y., Miyazaki, Y., Iida, T. 1991. Microgravity experiment of vapor/liquid reorientation induced by capillary force. Rep. Microgravity Exp. Aircraft 1 (2) : 27-35.

Furukawa, M., Ishii, Y., Iida, T., Komori, M., Furuhama, K., Kawamoto, K., Miyaji, T., Miyazaki, Y. 1992. Observation of two-phase flow patterns in the evaporation under microgravity environment. Rep. Microgravity Exp. Aircraft 2 (2) : 47-58.

Hoehn, A., Chamberlain, D. J., Clowson, J. M., Forsyth, S. W., Hanna, D. S., Horner, M. B., Scovazzo, P., Sterrett, K. S., Stodieck, L. S., Todd, P. W., Henenga, A. G., Kliss, M. H. 1997. On-Orbit and Ground Performance of the PGBA Plant Growth Facility. SAE Technical Paper Series 972366.

Imaishi, N. 1994a. Interface phenomenon. In "Microgravity" (ed. by Ishikawa, M., Hibiya, T.). Baifukan, Tokyo, p 42-59.

Imaishi, N. 1994b. Effect of residual gravity. In "Microgravity" (ed. by Ishikawa, M., Hibiya, T.). Baifukan, Tokyo, p 76-86.

Kitaya, Y., Tani, A., Goto, E., Saito, T., Takahashi, H. Development of a plant growth chamber unit for growing plants over a long-term life cycle under microgravity conditions. Adv. Space Res. (in press)

Kudo, I. 1994. Experimental tools for generating microgravity. In "Microgravity" (ed. by Ishikawa, M., Hibiya, T.). Baifukan, Tokyo, p 183-211.

Marui, T., Murata, T., Inoue, M., Sakurada, T. 1995. Surface and Interface. Kougyochosakai, Tokyo, pp 306.

Nagaoka, S., Yamawaki, T., Murakami, K., Takaoki, M., Gosozono, T., Negishi, N., Kamimura, K., Kajimura, T. 1994. Infection and collection of fluids into cell culture chamber under microgravity. Rep. Microgravity Exp. Aircraft 4 (1) : 42-52.

Ono, S. 1997. Surface Tension. Ed.12, Kyoritsushuppan, Tokyo, pp 133.

Suzuki, M., Endo, A., Yamashita, Y., Sato, M., Nonaka, T., Hasegawa, K., Kikuta, R., Kawasaki, K., Ohta, K., Tada, T., Kawasaki, H. 1997. Interface phenomena of solid surface with a gradient of wettability. Rep. Microgravity Exp. Aircraft 8 (1) : 17-25.

Tani, A., Okuma, T., Tanaka, S., Yasuda, H. 1998. Water vapor control and condensed water recovery systems for plants cultivation under microgravity. In "Proceedings of International Conference on Closed Ecological Systems for Terrestrial and Space Applications.” CELSS Soc., Tokyo, p 91-94.

Yoda, S., Kimura, H., Asai, S., Ishikura, S., Nakai, S., Saito, M. 1992. Experiments on bubble behavior under the effect of centrifugal force. Rep. Microgravity Exp. Aircraft 2 (1): 40-49. 


\title{
パラボリックフライト中の低重カおよび微小重カ下での
} 親水性瀻維を用いた吸水システムの性能評価

\author{
谷晃・斎藤高弘 ${ }^{* 1}$ ・北宅善昭 ${ }^{* 2}$ ・高橋秀幸*3 ・後藤 英 司*4 \\ 東海大学開発工学部， ${ }^{* 1}$ 宇都宮大学農学部， ${ }^{* 2}$ 大阪府立大学農学部 \\ *3 東北大学遺伝生態研究センター, ${ }^{* 4}$ 東京大学大学院農学生命科学研究科
}

微小重力下扔よび $g$ ジッター存在下で水と空気の混在する容器から吸水し, 植物栽培培地へ供 給するために, 親水性繊維を用いた吸水システムを開発し, 飛行機を用いた放物線飛行で実現した 0.01 0.02 gの低重力下でその性能を調べた. 実験に用いた容器は, 濾過用の吸水口を持つフラス コであった. 親水性緘維を容器の内側に配置し, 一端を吸水口の内側に取り付けた. 容器内の水量 が $220 \mathrm{~mL}$ で親水性䋐維を配置していない場合, 水は内壁に沿って $5 \mathrm{~mm}$ 上昇しただけで, 吸水口 まで達しなかった。一方, 親水性紼維を用いた場合, 水は繊維に沿って吸水口に達しローラーポン プによって吸引できた。吸水量は, 容器内の水の量や繊維の種類によって異なった。 パラボリック フライト中に容器を浮遊させた場合 $\left(10^{-4} \mathrm{~g}\right)$ も, 容器内の水は緘維に沿って広がり, 水膜の形成 が観察された。このように $10^{-4} \mathrm{~g}$ の微小重力下でも水を親水性繊維表面に集めることが可能で あった。これらの結果は, 微小な重力が突発的に起こる $g$ ジッター下㧍よび微小重力下で, 本吸水 システムを用いることで容器から吸水できることを示す。低重力下で水のみを吸引することは不 可能であったが, 植物へ水を供給する場合, 根圏に気相, 液相が共存するため, 気液分離の必要は ないと考えられる。 